\title{
Importance of intellectual capital disclosure in Spanish universities
}

\author{
Yolanda Ramírez Córcoles \\ Universidad de Castilla-La Mancha (Spain) \\ Yolanda.Ramirez@uclm.es
}

Received May, 2012

Accepted July, 2013

\section{Abstract}

Purpose: The increasing social concern about establishing procedures of accountability and ensuring information transparency in public universities prompted us to raise the need to disclose information on their intellectual capital.

Design/methodology/approach: In this study we developed a questionnaire which was sent to members of the Social Councils of Spanish public universities, in order to identify which intangible elements university stakeholders demand most.

Findings: The results of this research demonstrate how important it is for Spanish public universities to provide information on their intellectual capital in order to satisfy their stakedolders' information needs.

Practical implications: The results of this research lead us to recommend that universities include in their accounting statements the information on intellectual capital demanded by the different stakeholders.

Originality/value: No previous research was conducted for Spanish universities. Our results represent a starting point for public universities to identify which is the most requested information about intellectual capital.

Keywords: Institutions of higher education, Intellectual capital, Disclosure

Jel Codes: I23 


\section{Introduction}

European higher education institutions are currently immersed in a process of profound change, the intention of which is to improve the effectiveness, efficiency and transparency of these institutions with the aim of contributing to the development and improvement of the competitiveness of the European economy (Ramírez, 2011; Secundo, Margheritam, Elia \& Passiante, 2010; Sánchez, Elena \& Castrillo, 2009). Some of the most significant changes are: new methods for measuring the performance and efficiency of universities; the creation of European-wide accreditation agencies; new assessment processes and systems to ensure quality which, in turn, strengthen transparency and accounting statements; the institutionalisation of new financing mechanisms; reforms of national legislation to increase the level of universities' independence and the implementation of new tools to improve internal management.

Given this situation, the information transparency of university institutions acquires even greater significance. A need exists to conduct a profound reform and modernisation of the university system with regards to the presentation of information which takes into account the new information demands of its users.

However, accounting in the public sector has traditionally been somewhat short-sighted since the tools of transparency have always focused on financial and budget information (Martín \& Moneva, 2009), ignoring other types of information such as data about the social responsibility of their activities (Melle, 2007) or the key intangible elements in their value creation (Bezhani, 2010). Public universities are a prime example of this, since the information provided focuses on guaranteeing financial control of the organisation without paying attention to the needs of other groups of interest (Martín, 2006). Gray (2006) consider that the information supplied in traditional financial reports is not enough, highlighting the need to establish more extensive communication and accounting mechanisms which take into account the needs of the different groups of interest.

It is useful to remember that accounting research is currently focused on the utility paradigm, which stresses the need for accounting information to be truly relevant to good decision making by its users (Ramírez, Santos \& Tejada, 2012). Consequently, given the new characteristics of the present socio-economic climate of the European higher education sector, we believe that universities should provide all the relevant information on their activities and the key factors of their success - their intangible resources. So, in our opinion, universities will have to pay greater attention to their different stakeholders and their respective information interests when designing their communication strategy. It will be necessary to include relevant information on their intangible assets, such as the quality of the institutions, their social and 
environmental responsibility, the capacities, competences and skills of their staff, etc.

So, this study was taken to seek out the opinion of the university stakeholders regarding the importance they give to completing the information from university financial statements with information relating to these institutions' intangible elements.

In this sense, the main aim of this study is to determine which intellectual capital information Spanish public universities demand most.

To this end we will first review the existing literature on the importance of intellectual capital in higher education institutions. Then we will define the scope of the empirical study conducted and the methodology used and, finally, we will present our results and conclusions.

\section{Intellectual capital in higher education institutions}

The presentation of information about intellectual capital has now become of prime importance in institutions of higher education, mainly because knowledge is the main output and input of these institutions. Universities produce knowledge, either through technical and scientific research (the results of investigation, publications, etc) or through teaching (students trained and productive relationships with their stakeholders). Their most valuable resources also include their teachers, researchers, administration and service staff, university governors and students, with all their organisational relationships and routines (Warden, 2003; Leitner, 2004; Ramírez, Lorduy \& Rojas, 2007). It is true to say then that universities' input and output are intangible (Cañibano \& Sánchez, 2008, page 9). The higher education institutions are, therefore, an ideal framework for the application of the ideas related to intellectual capital theory (Zhao \& Ordóñez de Pablos, 2009).

Intellectual capital, when referred to a university, is a term used to cover all the institution's non tangible or non physical assets, including processes, capacity for innovation, patents, the tacit knowledge of its members and their capacities, talents and skills, the recognition of society, its network of collaborators and contacts, etc. The intellectual capital is the collection of intangibles which "allows an organisation to transfer a collection of material, financial and human resources into a system capable of creating value for the stakeholders" (European Commission, 2006, page 4).

Another reason for the importance and necessity of establishing a model for the dissemination of universities' intellectual capital is the existence of continual demands for greater information and transparency about the use of public money (Warden, 2003), mainly due to the continuous process of both academic and financial decentralisation which institutions of higher education are currently engaged in (Ramírez, 2013). As leading producers of knowledge, universities are 
now key players in the current economy and their activities are therefore subject to much greater scrutiny by the wider community (European University Association, 2006, page 19). Therefore the appropriate presentation of institutional communication has become one of the principal mechanisms by which institutions of higher education render accounts.

In our opinion, an improvement in university accounting systems would be achieved by the drafting and presentation of a new report complementary to the current financial statements the Intellectual Capital Report. A set of indicators would show the information most demanded by different stakeholders regarding the institution's intangible resources.

The obligation to present this intellectual capital report in the higher education system would be a crucial step towards the new university management, achieving so a double objective: to identify and measure intangibles for management purposes and to provide useful information to stakeholders.

However, in most countries there exists no obligation or recommendation for universities to present information on their intellectual capital. The only exceptions are Austria, where universities have been obliged to present an intellectual capital report since January 2007 (Federal Ministry of Education, Science and Culture, 2006), and Sweden, where it has been compulsory since 1996 for universities to publish environmental reports (Arvidsson, 2004). This lack of obligation or even simple recommendations from university administration or political authorities on presenting information on intellectual capital will be contrasted in our study by what we see as the need for traditional financial information to be complemented by other indicators relating to the intangible aspects most demanded by the various stakeholders of universities.

\section{Empirical study}

The need for universities to have a greater involvement with their wider community and the general concern to ensure the informational transparency of these institutions prompted us to try to identify which is the positioning of Spanish public universities on the necessity of disclosing information on their intellectual capital. So, the fundamental objective of the empirical study is to determine the extent to which different users are demanding information relating to the intellectual capital of Spanish public universities in order to make the right decisions, identifying which intangible resources are the most relevant for publication. To this end, a questionnaire was designed and sent to every member of the Social Councils of Spanish public universities. It was thought that these participants would provide a good example of the attitude of university information users since they represent the different social groups connected with universities. Once the different opinions were recorded and analyzed, we were 
in the position of confirming the need for universities to offer information on their intellectual capital.

\section{Methodology and data collection}

In order to achieve the previously mentioned objectives, in mid-May 2011 an online questionnaire requesting the opinion of the members of the Social Councils was sent to all Spanish public universities. The methodology of the study is outlined in the data sheet attached in table 1.

\begin{tabular}{|l|l|}
\hline Analysis group & $\begin{array}{l}\text { Users of accounting information from Spanish } \\
\text { public universities }\end{array}$ \\
\hline Universe & $\begin{array}{l}\text { Members of the Social Councils of Spanish } \\
\text { public universities (1.094) }\end{array}$ \\
\hline Size of sample & 247 \\
\hline $\begin{array}{l}\text { Information collection } \\
\text { technique }\end{array}$ & On line survey \\
\hline Period of field work & May-July 2011 \\
\hline Average time per survey & 7 minutes 45 seconds \\
\hline Software & SPSS $^{\circledR}$ v. 17 \\
\hline
\end{tabular}

Table 1. Technical details

Defining the population and selecting the sample

After reviewing the literature dedicated to the analysis of stakeholders in universities ( $O$ 'dwyer, 2005; Jongbloed, Enders \& Salerno, 2008; Okunoye, Frolic \& Crable, 2008; Gaete, 2009; Larrán, López \& Calzado, 2010), a certain consensus was detected once the following users of the accounting information of the higher education institutions were identified: the public administration, bodies of university government, students, teaching and research staff, administration and service staff, unions, private and public organisations with plans to employ university graduates or to apply the research generated at the institution, the media, foundations or any other party interested in university activity.

Two important factors were used to justify the population to be studied:

- members of the Social Councils of Spanish public universities were considered to provide a good sample of the feelings of university information users, as they represent the various social groups with links to the universities

- these members are familiar with the accounting information published by the universities since they are responsible for approving the universities' annual accounts. 
Following the analysis of the composition of the Social Councils, the members were divided into these seven groups:

- university governors (vice-chancellor, general secretary, council secretary and manager)

- teaching and research staff

- students

- administration and service staff

- representatives of business organisations

- representatives of union organisations

- representatives of the public administrations.

The population to be studied was therefore composed of the 1.904 members of the Social Councils of Spanish public universities. Replies were received from 247 members, $22.57 \%$ of the total. The size of the sample was considered sufficient, since in a binomial population the estimation error would be $5.37 \%$ for a reliability level of $95 \%$.

\section{Information collection and treatment}

The information was collected via an online survey. An email was sent to the members of the Spanish universities' Social Councils, requesting their members to take part in our research. The questionnaire consists of 5-point Likert scales questions. So, those surveyed were asked to rate on a 5-point Likert scale the importance they gave to universities publishing information on the different intangible elements by Spanish public universities (human capital, structural capital and relational capital). On the scale 1 corresponds to "not at all important" and 5 "very important".

A descriptive analysis of the replies was conducted according to the characteristics of each of the questions.

\section{Analysis the results of the empirical study}

In order to identify the intangible assets about which users of university accounting information consider it relevant or very relevant to publish information, we set as a requirement that the assets had to reach a mean value or a median equal or higher than 4 points in combination with a minimum 25 of 4 points and a minimum 75 percentile of 5 points. 
In short, the intention is that most of the distribution of values is concentrated in high scores close to 5 points.

\section{- Human capital block}

Human capital is the sum of the explicit and tacit knowledge of the university staff (teachers, researchers, managers, administration and service staff) acquired through formal and non formal education and refresher processes included in their activities.

Table 2 shows the frequencies obtained by each of the 12 intangible elements related to the human capital block about which those surveyed were questioned.

\begin{tabular}{|c|c|c|c|c|c|c|c|}
\hline INTANGIBLE ASSET & Mean & Median & Mode & $\begin{array}{c}\text { Typical } \\
\text { deviation }\end{array}$ & Range & $\begin{array}{l}\text { Percentile } \\
25\end{array}$ & $\begin{array}{l}\text { Percentile } \\
\quad 75\end{array}$ \\
\hline $\begin{array}{l}\text { Typology of university staff (historical } \\
\text { data of growth or decrease in staff, } \\
\text { age structure of staff, contractual } \\
\text { conditions, etc.) }\end{array}$ & 3,66 & 4 & 4 & 0,76 & 3 & 3 & 4 \\
\hline $\begin{array}{l}\text { Academic and professional } \\
\text { qualifications of teaching and } \\
\text { research staff ( } \% \text { of doctors, \% civil } \\
\text { servants, etc.) }\end{array}$ & 4,52 & 5 & 5 & 0,60 & 3 & 4 & 5 \\
\hline $\begin{array}{l}\text { Mobility of teachers and researchers } \\
\text { (\% of teachers on fellowships, etc.) }\end{array}$ & 4,08 & 4 & 4 & 0,87 & 3 & 4 & 5 \\
\hline $\begin{array}{l}\text { Scientific productivity (books, articles } \\
\text { published, etc.) }\end{array}$ & 4,54 & 5 & 5 & 0,68 & 3 & 4 & 5 \\
\hline $\begin{array}{l}\text { Professional qualifications of } \\
\text { administration and service staff }\end{array}$ & 3,68 & 4 & 4 & 0,99 & 4 & 3 & 4 \\
\hline Mobility of graduates & 4,30 & 4 & 5 & 0,73 & 3 & 4 & 5 \\
\hline Efficiency of human capital & 4,49 & 5 & 5 & 0,74 & 3 & 4 & 5 \\
\hline $\begin{array}{l}\text { Teaching capacities and competences } \\
\text { (pedagogical capacity, teaching } \\
\text { innovation, teaching quality, language } \\
\text { proficiency, etc.) }\end{array}$ & 4,57 & 5 & 5 & 0,66 & 3 & 4 & 5 \\
\hline $\begin{array}{l}\text { Research capacities and competences } \\
\text { (research quality, participation in } \\
\text { national and international projects, \% } \\
\text { of doctor, six-year research periods, } \\
\text { etc.) }\end{array}$ & 4,63 & 5 & 5 & 0,62 & 2 & 4 & 5 \\
\hline Teamwork capacity & 4,04 & 4 & 4 & 0,79 & 3 & 4 & 5 \\
\hline Leadership capacity & 3,97 & 4 & 4 & 0,79 & 3 & 3 & 5 \\
\hline Training activities & 4,44 & 5 & 5 & 0,71 & 3 & 4 & 5 \\
\hline
\end{tabular}

(*) 5-point scale: (1: not at all important, 5: very important)

Table 2. Frequency analysis in the human capital block $\left(^{*}\right)$

One of the first conclusions that can be drawn from the data is the extremely high level of importance given to publishing the items of human capital. Most of the intangible assets give a mean value higher than 4 . There are three exceptions typology of university staff (3.66), professional qualifications of administration and service staff (3.68) and leadership capacity (3.97).

The analysis of the statistics of mean, median, mode, range, typical deviation, percentile 25 and 75 allows us to state that those surveyed consider the publication of the following intangible assets to be relevant or very relevant: research capacities and 
competences, teaching capacities and competences, scientific productivity, academic and professional qualifications of teaching and research staff, efficiency of human capital, training activities, mobility of teachers and researchers and teamwork capacity.

\section{- Structural capital block}

The second of the blocks of intellectual capital included in our survey, structural capital, consists of 14 intangible assets.

Structural capital is the explicit knowledge relating to the internal process of dissemination, communication and management of the scientific and technical knowledge at the university. Structural capital may be divided into:

- Organisational capital: this refers to the operational environment derived from the interaction between research, management and organisation processes, organisational routines, corporate culture and values, internal procedures, quality and the scope of the information system, etc.

- Technological capital: this refers to the technological resources available at the university, such as bibliographical and documentary resources, archives, technical developments, patents, licences, software, databases, etc.

Table 3 shows their frequencies.

It is important to note once again the high mean value given to the publication of information relating to the different intangible assets included in the structural capital block. From the analysis of the statistics we can classify as relevant or very relevant the inclusion of information on the following intangible assets: effort in innovation and improvement, intellectual property, management quality, research management and organisation, technological capacity, facilities and material resources for research and development, organisation of scientific, cultural and social events, information systems, evaluation and qualification processes and activities within the institution, teaching management and organisation and finally facilities and material resources supporting pedagogical qualification and innovation. 


\begin{tabular}{|c|c|c|c|c|c|c|c|}
\hline INTANGIBLE ASSET & Mean & Median & Mode & $\begin{array}{c}\text { Typical } \\
\text { deviation }\end{array}$ & Range & $\begin{array}{c}\text { Percentile } \\
25\end{array}$ & $\begin{array}{l}\text { Percentile } \\
\quad 75\end{array}$ \\
\hline $\begin{array}{l}\text { Facilities and material resources } \\
\text { supporting pedagogical qualification } \\
\text { and innovation }\end{array}$ & 4,09 & 4 & 4 & 0,71 & 3 & 4 & 5 \\
\hline $\begin{array}{l}\text { Facilities and material resources for } \\
\text { research and development }\end{array}$ & 4,40 & 4 & 5 & 0,66 & 3 & 4 & 5 \\
\hline $\begin{array}{l}\text { Evaluation and qualification } \\
\text { processes and activities within the } \\
\text { institution }\end{array}$ & 4,28 & 4 & 5 & 0,73 & 3 & 4 & 5 \\
\hline Structural organisation & 3,98 & 4 & 5 & 0,97 & 3 & 3 & 5 \\
\hline $\begin{array}{l}\text { Teaching management and } \\
\text { organisation (academic networks, } \\
\text { teaching exchanges, teaching } \\
\text { incentives, etc.) }\end{array}$ & 4,26 & 4 & 4 & 0,69 & 3 & 4 & 5 \\
\hline $\begin{array}{l}\text { Research management and } \\
\text { organisation (internal } \\
\text { communication of results, efficient } \\
\text { management of research projects, } \\
\text { research incentives, theses read, } \\
\text { etc.) }\end{array}$ & 4,47 & 5 & 5 & 0,60 & 3 & 4 & 5 \\
\hline $\begin{array}{l}\text { Organisation of scientific, cultural } \\
\text { and social events }\end{array}$ & 4,40 & 4 & 5 & 0,68 & 3 & 4 & 5 \\
\hline $\begin{array}{l}\text { Productivity of administrative, } \\
\text { academic and support services }\end{array}$ & 3,98 & 4 & 4 & 0,77 & 3 & 3 & 5 \\
\hline Organisational culture and values & 4,04 & 4 & 4 & 0,80 & 3 & 3 & 5 \\
\hline $\begin{array}{l}\text { Effort in innovation and } \\
\text { improvement (expenditure on } \\
\text { innovation, staff working on } \\
\text { innovation) }\end{array}$ & 4,55 & 5 & 5 & 0,58 & 3 & 4 & 5 \\
\hline Management quality & 4,51 & 5 & 5 & 0,60 & 4 & 4 & 5 \\
\hline $\begin{array}{l}\text { Information system (documented } \\
\text { processes, databases, use of ITC) }\end{array}$ & 4,38 & 4 & 5 & 0,63 & 2 & 4 & 5 \\
\hline $\begin{array}{l}\text { Technological capacity (total } \\
\text { expenditure on technology, } \\
\text { availability and use of computer } \\
\text { programs, use of intranet/Internet, } \\
\text { etc.) }\end{array}$ & 4,45 & 5 & 5 & 0,61 & 3 & 4 & 5 \\
\hline $\begin{array}{l}\text { Intellectual property (patents, } \\
\text { licenses, etc.) }\end{array}$ & 4,52 & 5 & 5 & 0,64 & 3 & 4 & 5 \\
\hline
\end{tabular}

(*) 5-point scale: (1: not at all important, 5: very important)

Table 3. Frequency analysis in the structural capital block $(*)$

- $\quad$ Relational capital block

Relational capital refers to the extensive collection of economic, political and institutional relations developed and upheld between the university and its non academic partners: enterprises, non profit organisations, local government and society in general. It also includes the perception others have of the university: its image, appeal, reliability, etc.

This block analyses the importance university accounting information users give to the publication of information concerning intangible assets within the relational block. The questionnaire includes 16 intangible assets reflected in the following descriptive statistics (see table 4 ). 


\begin{tabular}{|c|c|c|c|c|c|c|c|}
\hline INTANGIBLE ASSET & Mean & Median & Mode & \begin{tabular}{c|} 
Typical \\
deviation
\end{tabular} & Range & $\begin{array}{l}\text { Percentile } \\
25\end{array}$ & $\begin{array}{l}\text { Percentile } \\
\quad 75\end{array}$ \\
\hline $\begin{array}{l}\text { Efficiency of graduate teaching } \\
\text { (average duration of studies, dropout } \\
\text { rate, graduation rate, etc.) }\end{array}$ & 4,53 & 5 & 5 & 0,64 & 3 & 4 & 5 \\
\hline Student satisfaction & 4,61 & 5 & 5 & 0,68 & 3 & 4 & 5 \\
\hline Graduate employability & 4,75 & 5 & 5 & 0,50 & 3 & 5 & 5 \\
\hline $\begin{array}{l}\text { Student relations (capacity for } \\
\text { responding to student needs, } \\
\text { permanent relations with ex- } \\
\text { students, etc.) }\end{array}$ & 4,21 & 4 & 4 & 0,60 & 3 & 4 & 5 \\
\hline $\begin{array}{l}\text { Relations with the business world } \\
\text { (spin-offs, contracts and R\&D } \\
\text { projects, etc.) }\end{array}$ & 4,74 & 5 & 5 & 0,57 & 4 & 5 & 5 \\
\hline $\begin{array}{l}\text { Relations with society in general } \\
\text { (institutional representation in } \\
\text { external organisations, collaboration } \\
\text { on national and international } \\
\text { projects, etc.) }\end{array}$ & 4,48 & 5 & 5 & 0,60 & 3 & 4 & 5 \\
\hline $\begin{array}{l}\text { Application and dissemination of } \\
\text { results (dissemination of results, } \\
\text { appropriateness of research) }\end{array}$ & 4,62 & 5 & 5 & 0,55 & 2 & 4 & 5 \\
\hline Relations with the media & 3,94 & 4 & 4 & 0,85 & 3 & 3 & 5 \\
\hline University's image & 4,56 & 5 & 5 & 0,65 & 2 & 4 & 5 \\
\hline $\begin{array}{l}\text { Collaborations and contacts with } \\
\text { public and private organisations }\end{array}$ & 4,40 & 5 & 5 & 0,68 & 2 & 4 & 5 \\
\hline Collaboration with other universities & 4,51 & 5 & 5 & 0,54 & 2 & 4 & 5 \\
\hline Strategic links & 4,35 & 4 & 4 & 0,63 & 3 & 4 & 5 \\
\hline Relations with quality institutions & 4,38 & 4 & 5 & 0,70 & 3 & 4 & 5 \\
\hline $\begin{array}{l}\text { University's regional, national and } \\
\text { international reputation }\end{array}$ & 4,41 & 5 & 5 & 0,69 & 3 & 4 & 5 \\
\hline Social and cultural commitment & 4,47 & 5 & 5 & 0,65 & 3 & 4 & 5 \\
\hline Environmental responsibility & 4,44 & 5 & 5 & 0,70 & 3 & 4 & 5 \\
\hline
\end{tabular}

(*) 5-point scale: (1: not at all important, 5: very important)

Table 4. Frequency analysis in the relational capital block $(*)$

The first interesting result is the high mean scores awarded to all the intangible assets included in the relational block. The lowest score was 3.94 for the intangible asset, "relations with the media". The other intangible assets in this block achieved values above 4 and in $43.7 \%$ of the cases the value was higher than 4.5 . These high values show that, a priori, the intangible assets related to relational capital are those for which publication is most relevant.

According to the results obtained from the analysis of the different statistics it may be concluded that the users of the accounting information of Spanish public universities feel that it is relevant to publish all the assets included in the relational block of our questionnaire, except for information concerning relations with the media.

Finally, in order to classify any of the intangible items as essential to publish, they must achieve a mean value of over above 4.5 and a median of 4 or more points, in conjunction with a minimum percentile of 25 scoring 4 points and a minimum percentile of 75 of 5 points. 
The analysis of the data obtained from the various statistics (mean, median, mode, range typical deviation, 25 and 75 percentiles) led to classifying the following intangible elements as essential to publish (see Figure 1):
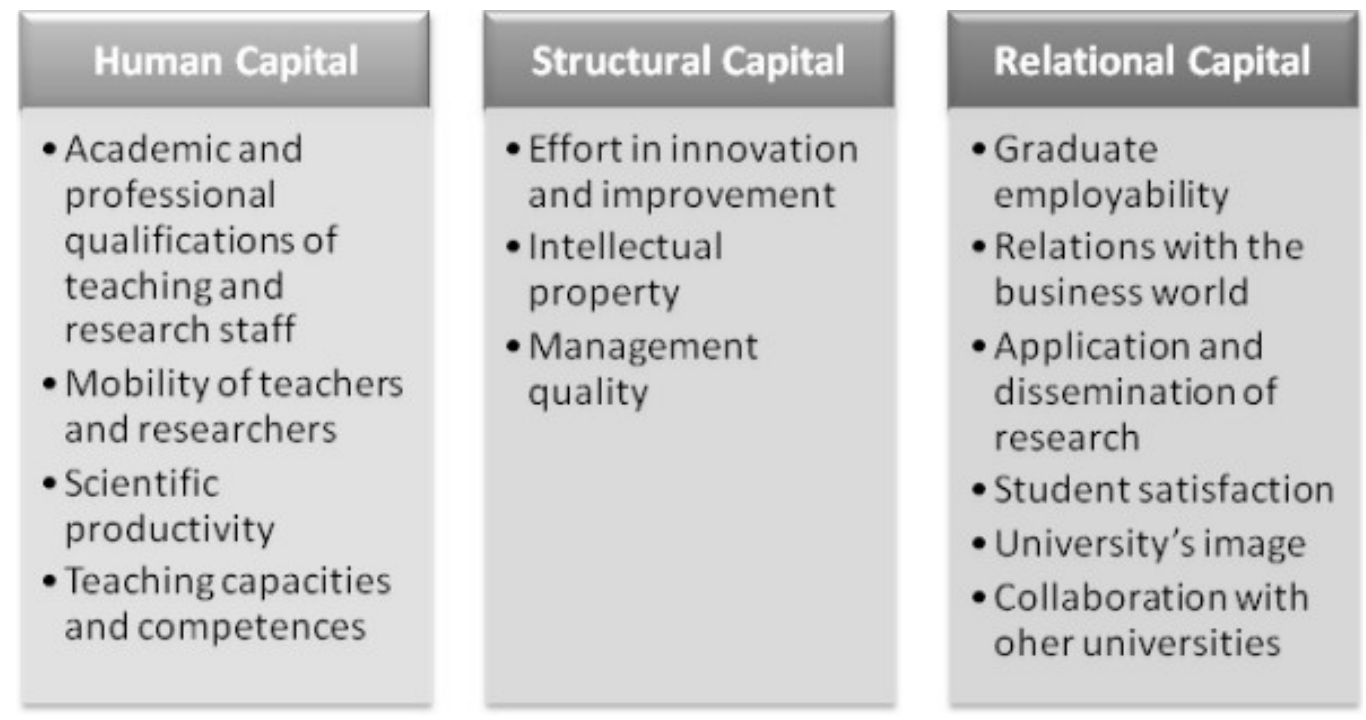

Figure 1. Essential intangible elements

\section{Conclusions}

In the current context of the knowledge society the European higher education institutions are characterized by being immersed in a process of profound changes to improve effectiveness, efficiency and transparency, which directly affects the conceptualization and operation of these institutions and their reporting model.

In this scenario, and given the growing social concern about establishing processes of accountability in public higher education institutions and ensuring information transparency in these institutions, there is a need for major changes in the existing communication systems, such as the information on intellectual capital that these institutions should provide.

So, through the presentation of this new information the external stakeholders may have at their disposal reliable and comparable information on the performance of institutions of higher education in all their areas of activity and may thus form judgments and take decisions.

In this situation, the major objective of this study was to assess the degree of importance attached by members of the Social Councils of the Spanish public universities to the need to follow a proactive policy of publication of information on intellectual capital.

The results obtained in the empirical study show the great importance that the stakeholders give to the disclosure of the intellectual capital in universities. Specifically, it is considered 
essential the disclosure of the following intangible elements: academic and professional qualifications of the teaching and research staff, mobility of teachers and researchers, scientific productivity and teaching capacities and competences (Human Capital); effort in innovation and improvement, intellectual property and quality management (Capital Structure); as well as the graduate employability, relations with the business world, application and dissemination of research, students' satisfaction, the university's image and collaboration with other universities (Relational Capital).

In our opinion, and considering the results of the empirical study carried out, it is absolutely necessary for universities to disclose information on their intangibles through the filing of an intellectual capital report. It will be a healthy exercise of transparency from these institutions to provide users with access to this type of information, which is relevant for decision making.

\section{References}

ARVIDSSON, K. (2004). Environmental management at Swedish universities. International Journal of Sustainability in Higher Education, 5(1): 91-99. http://dx.doi.org/10.1108/14676370410512616

BEZHANI, I. (2010). Intellectual capital reporting at UK universities. Journal of Intellectual Capital, 11(2): 179-207. http://dx.doi.org/10.1108/14691931011039679

CAÑIBANO, L.; SÁNCHEZ, P. (2008). Intellectual Capital Management and Reporting in Universities and Research Institutions. Estudios de Economía Aplicada, 26(2): 7-26.

EUROPEAN COMMISSION (2006). Ricardis: Reporting intellectual capital to augment research, development and innovation in SMEs. Report to the Commission of the High Level Expert Group on Ricardis, available at: http://ec.europa.eu/invest-in-research/pdf/download_en/20062977_web1.pdf. (Last access date: February 20th, 2011)

EUROPEAN UNIVERSITY ASSOCIATION (2006). The rise of knowledge regions: emerging opportunities and challenges for universities. Bruselas: European University Association. Available at: http://www.eua.be.(Last access date: February 20th, 2011).

FEDERAL MINISTRY OF EDUCATION, SCIENCE AND CULTURE (2006). Verordnung ueber die Wiessenbilanz (Wissensbilanz-Verordnung-WBV), BGB1, II Nr. 63/2006. Available from: http://www.bmbwk.gv.at/universiteeten/recht/gesetze/wbv/wbv.xml. (Last access date: February 20th, 2011).

GAETE, R.A. (2009). Participación de los stakeholders en la evaluación del comportamiento socialmente responsable de la gestión universitaria: perspectivas, obstáculos y propuestas. Congreso de la Asociación Española de Contabilidad y Administración de Empresas (AECA). Valladolid (Spain). 
GRAY, R.H. (2006). Social, environmental and sustainability reporting and organizational value creation? Whose value? Whose creation?. Accounting, Auditing and Accountability Journal, 19(6). http://dx.doi.org/10.1108/09513570610709872

JONGBLOED, B.; ENDERS, J.; SALERNO, C. (2008). Higher education and its communities: Interconnections, interdependencies and a research agenda. Higher Education, 56(3): 303324. http://dx.doi.org/10.1007/s10734-008-9128-2

LARRÁN, M.; LÓPEZ, A.; CALZADO, M.Y. (2010). Expectativas de los stakeholders en las Universidades públicas españolas: un estudio empírico. XIV Encuentro ASEPUC. A Coruña (Spain).

LEITNER, K.H. (2004). Intellectual Capital reporting for universities: conceptual background and application for Austrian Universities. Research Evaluation, 13(2): 129-140. http://dx.doi.org/10.3152/147154404781776464

MARTÍN, E. (2006). La rendición de cuentas en las universidades públicas españolas: un análisis de la información revelada en los estados financieros. Presupuesto y Gasto Público, 43: 39-62.

MARTÍN, E.; MONEVA, J.M. (2009). Análisis de la rendición de cuentas de las Universidades desde un enfoque de responsabilidad social. Paper presented at the Workshop sobre Responsabilidad social, Gobierno corporativo y Transparencia informativa, Granada.

MELLE, M. (2007). La responsabilidad social dentro del sector público. Ekonomiaz, 65: 84-107.

O'DWYER, B. (2005). User needs in Sustainability Reporting: a perspective from stakeholders in Ireland. European Accounting Review, 14(4). http://dx.doi.org/10.1080/09638180500104766

OKUNOYE, A.; FROLIC, M.; CRABLE, E. (2008). Stakeholder influence and ERP implementation in higher education. Journal of Information Technology Case and Application Research, 10(3): 9-38.

RAMÍREZ, Y. (2011). New management in Spanish universities: introducing Balanced Scorecard. International Journal of Learning and Intellectual Capital, 8(4): 359-377.

RAMÍREZ, Y. (2013). Intellectual capital management and reporting in European higher education institutions. Intangible Capital, 9(1): 1-19.

RAMÍREZ, Y.; LORDUY, C.; ROJAS, J.A. (2007). Intellectual capital management in Spanish Universities. Journal of Intellectual Capital, 8(4): 732-748. http://dx.doi.org/10.1108/14691930710830873

RAMÍREZ, Y.; SANTOS, J.F.; TEJADA, A. (2012). Utilidad del actual modelo de información contable de las universidades públicas españolas. Cuadernos aragoneses de economía, 22(1-2): 121-150. 
SÁNCHEZ, P.; ELENA, S.; CASTRILLO, R. (2009). Intellectual capital dynamics in universities: a reporting model. Journal of Intellectual Capital, 10(2): 307-324. http://dx.doi.org/10.1108/14691930910952687

SECUNDO, G.; MARGHERITAM, A.; ELIA, G.; PASSIANTE, G. (2010). Intangible assets in higher education and research: mission, performance or both?. Journal of Intellectual Capital, 11(2): 140-157. http://dx.doi.org/10.1108/14691931011039651

WARDEN, C. (2003). Managing and Reporting Intellectual Capital: New Strategic Challenges for HEROs. IP Helpdesk Bulletin, 8: 5-8.

ZHAO, J.; ORDÓÑEZ DE PABLOS, P. (2009). School innovative management model and strategies: the perspective of organizational learning. Information Systems Management, 26(3): 241-251. http://dx.doi.org/10.1080/10580530903017781

Intangible Capital, 2013 (www.intangiblecapital.org) 